\title{
Real-time RT-PCR systems for CTC detection from blood samples of breast cancer and gynaecological tumour patients (Review)
}

\author{
ULRICH ANDERGASSEN, ALEXANDRA C. KÖLBL, SVEN MAHNER and UDO JESCHKE \\ Department of Gynecology and Obstetrics, Ludwig-Maximilians-University of Munich, D-80337 Munich, Germany
}

Received October 13, 2015; Accepted November 15, 2015

DOI: $10.3892 / o r .2016 .4608$

\begin{abstract}
Cells, which detach from a primary epithelial tumour and migrate through lymphatic vessels and blood stream are called 'circulating tumour cells'. These cells are considered to be the main root of remote metastasis and are correlated to a worse prognosis concerning progression-free and overall survival of the patients. Therefore, the detection of the minimal residual disease is of great importance regarding therapeutic decisions. Many different detection strategies are already available, but only one method, the CellSearch ${ }^{\circledR}$ system, reached FDA approval. The present review focusses on the detection of circulating tumour cells by means of realtime PCR, a highly sensitive method based on differences in gene expression between normal and malignant cells. Strategies for an enrichment of tumour cells are mentioned, as well as a large panel of potential marker genes. Drawbacks and advantages of the technique are elucidated, whereas, the greatest advantage might be, that by selection of appropriate marker genes, also tumour cells, which have already undergone epithelial to mesenchymal transition can be detected. Finally, the application of real-time PCR in different gynaecological malignancies is described, with breast cancer being the most studied cancer entity.
\end{abstract}

\section{Contents}

1. Introduction

2. CTC detection

3. Detection of CTCs in gynaecological malignancies

4. Conclusion

Correspondence to: PD Dr Ulrich Andergassen, Department of Gynecology and Obstetrics, Ludwig-Maximilians-University of Munich, Maistrasse 11, D-80337 Munich, Germany E-mail: ulrich.andergassen@med.uni-muenchen.de

Key words: circulating tumour cells, enrichment strategies, epithelial-mesenchymal transition, gynaecological malignancy, marker gene, prognosis, real-time PCR

\section{Introduction}

Gynaecological malignancies. A large number of different gynaecological malignancies affect women worldwide. The most common ones are cervical, ovarian, uterine, vaginal and endometrial carcinoma, breast cancer also belongs to this group but is not exclusively limited to women. All of these diseases are rather different in occurrence, screening possibilities and therapeutical concepts, but have in common, that still a large number of women are newly affected with one of these malignancies every year. Although death rates were decreasing in recent years, still many women die from their disease or the additional effects. The treatment strategies are mostly limited to surgery, radiation therapy, chemotherapy or hormonal therapy, but detection and combating of minimal residual disease could possibly improve death statistics greatly, as these circulating or disseminated tumour cells in the peripheral blood or bone marrow are considered as the origin of distant metastases.

General facts on circulating tumour cells (CTCs). Circulating tumour cells (CTCs) were first described in 1869 by Thomas Asworth, who found cells with the morphology of tumour cells in the blood of a person, who had died from metastatic cancer (1). Already 20 years later the 'seed and soil' hypothesis was drawn by Paget (2) and revised in 2003 by Fidler (3). It states, that for the formation of remote metastasis detached tumour cells on one hand and a certain organic background on the other hand is necessary. CTCs are rare events in the blood, following a Poisson distribution (4). Approximately $10^{6}$ tumour cells enter circulation every day, but $85 \%$ disappear within five min (5), so that only one CTC can be detected in $10^{5}-10^{7}$ mononuclear cells per $\mathrm{ml}$ blood (6). Only $2.5 \%$ of these CTCs are able to form micrometastases and $0.01 \%$ form macroscopic metastases (5), and CTCs are rather rare events in healthy persons $(7,8)$. The release of CTCs is regarded as one of the early steps during tumour formation (9-11). Patients (40\%), who still have tumour-free lymph nodes, already have CTCs in their blood stream (12), so that the measurement of CTCs is an important feature in tumour diagnostic. Therefore, the detection of CTCs is already included in international tumour staging systems $(13,14)$. They can also be helpful in predicting disease progression and in monitoring treatment efficiency (15). Metastatic cells often have different features than the primary tumour (15-18). They are frequently 
triple-negative for their hormone-receptor and Her2 status, which is linked to a more aggressive phenotype $(19,20)$ and a lack of Ki-67 expression, which contributes to resistance to chemotherapy (21). Therefore, an explicit characterization of CTCs $(22,23)$ is important for further application of clinical treatment.

When CTCs access bone marrow, they are called 'disseminated tumour cells' (DTCs) and they can reside there for many years, creating a kind of 'tumour reservoir' (24), which can give rise to metastasis at a later time (25). CTCs are highly heterogeneous (26) and in many cases show up with a triplenegative phenotype, concerning hormone and Her2-receptor status (16)

The limitation for CTC detection is the amount of blood available, so mostly an enrichment step is prepended in most methods (20).

CTCs and disease prognosis. The occurrence of metastasis causes an adverse prognosis in cancer patients $(27,28)$. CTCs do not only give rise to metastasis in distant organs, but also self-seed back to their original organs (29). The detection of CTCs in patients with metastatic breast cancer predicts a worse disease-free survival and worse overall survival (DFS and OAS) (30). The effect of the occurrence of CTCs in primary breast cancer was summarized by Saloustros and Mavroudis (31). It was analysed by the Light Cycler $^{\mathrm{TM}}$ method (32), with cytokeratin 19 (CK19) used as a marker gene (33). The occurrence of CTCs before administration of chemotherapy predicts an early metastatic relapse and disease-related death $(34,35)$. The persistence of CTCs after adjuvant chemotherapy also gives a hint towards decreased DFS and OAS. Therefore, occurrence of CTCs before and after chemotherapy are independent prognostic factors for worse clinical outcome (36). This prognostic value of CTC occurrence is even increased in different molecular subtypes of breast cancer, for example in estrogen-receptor (ER) negative type (37). Furthermore, the prognostic value of CTCs was analysed after hormone therapy and in follow-up. A persistence of CTCs after tamoxifen-treatment of hormone-receptor positive breast cancer is predictive for short DFS/OAS (38), as is the case for CTCs which can be found month and years after finalization of therapy (39). Thereby CTCs seem to have a significant clinical utility in cancer treatment.

\section{CTC detection}

CTC enrichment and detection methods. The detection of CTCs from peripheral blood is easier in handling and less exhausting for the patients, and is, therefore, the method of choice. The drawback of this methodology is, that the number of CTCs is rather small in relation to the surrounding blood cells, especially in non-metastatic cancer forms (40). Therefore, most methods implicate a CTC-enrichment (positive selection) or lymphocyte depletion (negative selection) procedure before starting the real CTC detection. Apart from the GILUPI ${ }^{\circledR}$ nanodetector, which should be able to isolate more tumour cells than the Veridex ${ }^{\mathrm{TM}}$-system (41), but is not yet established in the clinical routine, there are two main techniques of CTC enrichment: density gradient centrifugation either by Ficoll-Hypaque or by OncoQuick ${ }^{\circledR}$ or an immunomagnetic enrichment of tumour cells by cell surface antigens (42). The drawback of immunomagnetic enrichment of tumour cells is that CTCs are highly heterogeneous in their antigen expression (43-45), so that methods using EpCAM as an enrichment marker miss the population of EpCAM-negative CTCs (45). It would be more reasonable, to use tumour specific antigens for enrichment, for example CD176 (46). Furthermore, CTCs can be isolated by size (ISET). A great advantage of this technique is, that cells are not modified during enrichment, so they can subsequently be used for FISH or PCR characterization assays (47). The RosetteSep ${ }^{\mathrm{TM}}$ system offers a negative selection of tumour cells by crosslinking unwanted blood cells to erythrocytes, simplifying their removal during density gradient centrifugation $(48,49)$.

Many CTC detection methods combine a CTC enrichment step with further molecular analysis of tumour cells. The most important methods therefore should be summarized in the following: The 'gold standard' in CTC detection is still the CellSearch $^{\circledR}$ system (26), which is approved by the FDA (Food and Drug Administration) and has been validated by large clinical testings (50). The system first uses an immunomagnetic enrichment based on EpCAM [meaning that EpCAM negative cells are not detected by this system, which is one of the great drawbacks of this method; (45)], secondly the isolated cells are subsequently labelled fluorescently for DAPI, CD45 and CK19, so that CTCs could be undoubtedly detected $(7,51,52)$. The CTC-results of the CellSearch ${ }^{\circledR}$ system gives a prognostic patient information in respect to progression-free survival and overall survival (PFS and OAS, respectively (15). Already one circulating tumour cell in early breast cancer is a marker for a poor disease-free and overall survival, five or more CTCs found in a blood volume of $7.5 \mathrm{ml}$ are a marker for worse prognosis (53). Even more CTCs in metastatic breast cancer are a sign of impending progression of the disease (54-57). An interesting option for the future could be to combine the CellSearch $^{\circledR}$ system with ISET, as this method finds more CTC clusters, which develop during tumour cell division and could be important in metastatic processes (58). Apart from this method, there are protein-based strategies for CTC detection, like the EPISPOT-assay, which detects tumour cell specific proteins (59), so that only viable cells are found (26,60-62). By detection of cytokeratin 19 protein via EPISPOT-assay an active subset of breast cancer cells with metastatic properties can be detected (63). A detection of CTCs can be carried out by fluorescence in situ hybridization (FISH), which detects chromosome aberrations in the tumour cells $(64,65)$, or miRNA-profiling, as an altered miRNA expression profiling gives hints towards initiation and the progression of cancer (66). Also a detection of CTCs by microdevices, socalled 'CTC-chips' $(59,67)$, which capture EpCAM-expressing cells $(68,69)$ or microarrays can be done. The advantage of the microarray technology is, that a large number of genes can be analysed simultaneously, but a huge amount of RNA (1-2 $\mu \mathrm{g})$ is needed (70). This drawback is overcome by Pico Profiling, which does an expression profiling from as little as 10 tumour cells. Recently, also Raman spectroscopy (SERS) was used for circulating tumour cell detection (71). Another system for CTC detection is the so-called Ariol system, which is based on image capturing. Three fluorescent images of cell surface antigens like CK or EpCAM and one brightfield image of one 
cell are taken together for detection of tumour cells (72). Flow cytometry can also be used for CTC detection, with the advantage, that multiple cell parameters, such as DNA-content, cell size and cellular markers can be analysed simultaneously and has thereby advanced to be a specific method to monitor breast cancer patients receiving chemotherapy (73).

Additionally to all these methods mentioned above there are mRNA-based methods for CTC detection, which are the main focus of the present review and will be described in detail in the following sections.

RNA-based methods for CTC detection. The detection of viable CTCs by a detection of epithelial or tumour specific mRNAs by qRT-PCR is one of the most widely used techniques in the CTC-research field (74-78). QRT-PCR is the abbreviation for quantitative (real-time) reverse transcription PCR (79), which means that RNA is isolated from the tissue of interest (blood or fraction of a blood sample), is converted to cDNA by a reverse transcriptase reaction, which is then used in a real-time PCR reaction. For this quantification of RNA targets (80), which over the last years has turned into one of the mainstream research technologies (81), due to the high sensitivity of detection of small RNA amounts, even in a background of high total mRNA (70). A suitable detection chemistry, an instrument for monitoring of gene expression software, equipped with an adequate software are necessary (82). Thereby the time-point, when the PCR-product is first detected during cycling is recorded and can be translated into gene expression values. There are two different methods for quantification of PCR products: absolute and relative quantification (80). For absolute quantification it is necessary to generate a standard curve of known target numbers first, to later correlate real-time PCR recordings to a transcript number (83). In a relative quantification study internal reference genes, mostly housekeeping genes like GAPDH, 18S, RPLP0 or B2M (84) are run simultaneously with the genes of interest, and their gene expression values are correlated to those of the reference genes (85). The disadvantage of relative quantification is, that even reference genes can vary in gene expression, resulting in a misleading quantification (86). There are also two different options in the usage of detection chemistry: These could be non-probe based (like SYBR-Green), which requires the generation of a melting curve after completion of real-time PCR reaction (87), to distinguish specific PCR products from unspecific ones. More specific is the use of probe-based detection chemistry, which uses target specific PCR-primers, which can additionally be labelled with different fluorophores, making multiplexing possible (88). A higher sensitivity in the detection of target gene expression can also be achieved by Nested PCR-approaches (89). The advantages of the real-time PCR assays are: DNA is amplified and analysed in only one experimental step, targets, which differ widely in their copy number can be analysed during the same reaction, a rather small inter-assay variation, the quantitative capacity of the method $(90,91)$, and the possible suggestion of tumour spread by detection of tissue specific RNAs (92). There are also disadvantages, like the complicated handling of RNA samples due to the inherent presence of RNases, the use of oligo(dT)-primers, which on one hand contributes a high specificity to the reaction, but on the other hand requires the use of high quality RNA, the risk of a copurification of PCR inhibitors during the procedure, which could lower PCR efficiency $(93,94)$ and the risk of false-positive results due to minimal contaminations $(76,95,96)$. Furthermore, no morphological analysis of the detected tumour cells is possible (6) a heterogeneous expression of target genes might lead to a non-accurate enumeration of tumour cells, and many transcripts are expressed at low levels in normal blood cells $(97,98)$, leading to false-positive results, which makes the selection of target genes a crucial point in this experimental approach. Therefore, a stringent quality control has to be applied during the whole procedure, including use of reference guidelines, positive and negative controls, optimal sample quality and primer selection, adequate instrument care, and analytical sensitivity and specificity (99-103). If all of these steps are conducted carefully, reliable quantitative data can be obtained, which could in term lead to a personalized medicine (97), and even further: a detection of CTCs in early stage cancer could influence the application of different treatment options $(104,105)$.

A CTC-detection method assisted by real-time PCR is the AdnaTest ${ }^{\mathrm{TM}}$ (AdnaGen AG), in which tumour cells are first immunomagnetically enriched by epithelial and tumour specific antibodies and subsequently analysed by multiplexqPCR (51). This combination of markers helps to detect even rare CTCs, and thereby it was found that a major proportion of CTCs show characteristics of epithelial-mesenchymal transition (EMT, which is discussed later on) and have stem cell properties (106).

RT-PCR marker genes for CTC detection. The main purpose of RT-qPCR is to amplify epithelial or cancer specific genes (107), but such marker genes are sometimes also expressed in blood cells (108), or lack sensitivity (109), so that only a few molecules can be used for detection (110) and the choice of marker genes is one of the crucial points in the PCR-process.

CK 19 is one of the target genes frequently used in real-rime PCR for the detection of circulating tumour cells in clinical studies $(35,36,98,107,111-114)$. Silva et al (115) described also the use of EGFR VIII for the detection of CTCs, but the most widely described marker gene, especially in breast cancer analyses for RT-PCR is Mammaglobin A (hMAM) (116-118). The gene region of hMAM is frequently found to be amplified in breast cancer tissues (119). This expression is limited to the adult mammary gland (120) and related to mammary gland proliferation and differentiation (110,121-125), but is commonly absent in healthy breast tissue samples. The detection frequencies seem to vary (126-128), sensitivity of qPCR for detection of hMAM mRNA shows a broad range even in metastatic breast cancer (128-130), imposing doubt on the utility of this marker (118), but a combination of hMAM with survivin and hTERT increases the sensitivity of CTC detection (131), pointing towards the use of multimarker PCR (132). Furthermore, no correlation could be found between the expression of hMAM and nodal state, tumour size and grading $(109,121,132)$. The problem of the application of hMAM as a RT-PCR marker gene is, that it is an epithelial gene, and its expression could be altered during the process of EMT leading to false-negative results. 
Epithelial-mesenchymal transition. During the process of cell detachment from the primary tumour and the invasion of the blood vessel tumour cells often undergo the process of EMT, meaning that they lose their epithelial gene expression panels and cellular properties, like the ability of cell adhesion and the apical-basal cell polarity (70) and switch to a mesenchymal phenotype with increased invasiveness and resistance to apoptosis $(61,70,133)$ and furthermore, increased resistance to anticancer therapies $(134,135)$. The EMT dedifferentiation process is associated with an increased tumour cell aggressiveness (136). Patients who have CTCs without cytokeratin and other epithelial features but with mesenchymal markers have a worse prognosis for survival (137). The problem that the EMT-process bears for the detection of CTCs is, that such cells would escape to an enrichment via epithelial markers such as EpCAM (138), or cannot be detected by the use of epithelial marker genes.

Drawbacks and requirements of real-time PCR based tumour cell detection. The most serious drawbacks of the real-time PCR methodology for the detection of circulating tumour cells are, that, due to a large number of experimental steps and a certain variability therein, a comparison of different studies is difficult. Furthermore, there is a low reproducibility of the results obtained, caused by suboptimal standardization of the experimental processes. Additionally, frequently there are only small sample sizes available for analysis, so that a statistical evaluation of results could be difficult (111). Another disadvantage of the method is, that, by measurement of gene expression, CTC numbers present in a certain sample cannot be measured accurately, but can be characterized for a number of gene expression features (97). To overcome these drawbacks it is important to standardize first of all, the preanalytical phase, i.e. the sampling, then the isolation of the tumour cells as RNA from those cells, the inclusion of spiking experiments for quality control, and last but not least, the detection systems. Only then an intra- and inter-laboratory comparison of RT-qPCR studies would be possible (20).

\section{Detection of CTCs in gynaecological malignancies}

General facts. Detection and characterization of CTCs have recently become important issues in tumour diagnosis and management. As CTCs express a different gene panel than normal blood cells, a global gene expression profiling was carried out in order to distinguish normal donors from advanced cancer patients, and even to distinguish patients with different cancer entities (139). The challenge thereby is to differentiate CTCs from large numbers of surrounding lymphocytes with molecular techniques like multiplex real-time PCR (45). The group of De Albuquerque et al (140) developed such an assay based on immunomagnetic enrichment of tumour cells with subsequent real-time PCR analysis of the extracted cells. They were able to create a marker gene panel for the detection of CTCs from adenocarcinomas of 10 different organs. These different techniques for tumour cell detection gain in importance, as CTCs are more and more relevant not only for prognosis but also for therapy monitoring (141). However, it is becoming increasingly obvious, that CTC enrichment concepts based on EpCAM are no longer adequate for an extensive analysis of circulating tumour cells (142), as cells, which detach from a primary tumour undergo epithelial-mesenchymal transition (EMT), changing their gene and protein expression, escaping detection by most of the actually used methods. Furthermore, the EMT process is known to be extremely important for metastasis formation, so that especially tumour cells, which have undergone this process are important for clinical tumour management (143), creating the future need of new detection routines.

Recent developments for CTC detection in breast cancer. As breast cancer currently affects $6 \%$ of the female population (144), there is a huge medical research focus on this cancer entity. The real-time PCR methodology was widely used for CTC-detection from blood samples of breast cancer patients using marker genes such as CK19 (145). It was shown, that the occurrence of CK19-positive CTCs is correlated with the incidence of CK19-positive DTCs and is linked to a decreased survival of patients with early stage breast cancer. Cytokeratins in general were also, in another study, shown to be rather useful for CTC detection (146) especially in metastatic breast cancer patients. The gene for matrix metalloprotease was in contrast shown to be a useful marker for CTCs which already had undergone EMT (147). Another marker for detection of CTCs from breast cancer patient blood samples was h-MAM, which was demonstrated to be especially useful for evaluation of treatment efficacy and post-treatment monitoring of patients (148). As cancers often have a great heterogeneity in their gene expression many studies aim to find a suitable set of real-time PCR marker genes for the detection of CTCs. Xi et al (149) for example screened a set of 52 potential marker genes to find a set of three to eight marker genes for a number of cancer entities. De Albuquerque et al (140) found a set of marker genes, which could be helpful for the detection of CTCs from blood of metastatic breast cancer patients, Lasa et al (150) described an increase in CTC-detection rate by use of a marker set in comparison to the use of a single gene. A detection of two genes, the PTHRP and CK19 correlates furthermore with the incidence of remote metastasis (151), also giving hint to the use of a combination of marker genes for CTC detection and even more characterization.

Another important topic in CTC detection via real-time PCR is of course the quantification of tumour cells. Two studies were set up with cells from breast cancer cell lines added, in certain amounts, to blood samples of healthy donors, and processing these blood samples just like patient samples to real-time PCR. Both studies found, that cytokeratins are suitable PCR marker genes for CTC quantification from blood samples, promising new possibilities in CTC detection, treatment assessment and follow-up (152). The sensitivity of the CTC quantification could even be increased by a duplex PCR-assay, carried out subsequently after a negative enrichment (153).

A comparison of ISET technology for CTC detection and real-time PCR resulted in a statistically significant agreement of the two methods in their detection frequency (154), but a substantial variation in detection rates was seen comparing real-time PCR with the CellSearch ${ }^{\circledR}$ system and the AdnaTest, in which real-time PCR with CK19 and hMAM seemed to be the most sensitive of the three methods investigated (76). 
In clinical routine it would be of great importance, to correlate gene expression values to a disease prognosis. It was found that expression of the three genes STC-1, GalNacT and MAGE-3 could be correlated to the sentinel lymph node metastasis (155), and the expression of the 'brain metastasis selected markers' (BMSM), Her2, EGFR, HPSE and Notch1 in EpCAM negative CTCs gives a hint towards brain metastasis (156). Furthermore, in a number of studies the correlation of CTC incidence and treatment efficiency was regarded using real-time PCR. The presence of CK19-mRNA-positive cells before front-line chemotherapy seemed thereby to be linked to a worse progression-free and overall survival (157), and the reduction of CK19-mRNA positive tumour cells by chemotherapeutic treatment was associated with a better survival in metastatic breast cancer patients (158). Different effects of taxane-based and taxane-free chemotherapy regimens were also seen in the presence of CK19-mRNA-positive cells and thus on patient prognosis. Taxane-based chemotherapy eliminated more CTCs than the taxane-free therapy, thereby contributing to a better disease-free survival (159). Other studies used additional marker genes for CTC-detection in therapy monitoring, for example Wang et al (160) used EpCAM, Her2, Ki-67, hTERT and vimentin in addition to CK19, and found indeed no correlation of the expression of those marker genes to TNM-stage of the tumour but was able to show, that the consideration of such markers could help in selecting appropriate therapeutics and for monitoring treatment efficiency. A combination of EpCAM, Her2 and Muc-1 also gave insights into the correlation of CTC incidence and therapy outcome. It was confirmed again, that the presence of CTCs after chemotherapy may classify a high-risk subgroup of patients, with a high probability of development of remote metastasis (161). These findings were again affirmed by Mikulova et al (162), who used TOP1, TOP2, CTSD, ST6 and CK19 as marker genes. Also heterogeneity in the expression of these genes in different patients was found, and it was concluded, that CTC detection is particularly useful for therapeutic decisions. Also marker genes for epithelial-mesenchymal transition, TWIST1, SNAIL1, SLUG, ZEB and FOXC2, were tested as real-time PCR marker genes, and it was shown that neoadjuvant therapy is unable to eliminate CTCs expressing these markers (163). For luminal subtype breast cancer patients, a combination of the marker genes MET and CD47 seemed to be helpful for risk stratification and treatment decisions (164).

Considering the research done in recent years it has become incresingly clear, that the process of epithelial-mesencymal transition has to be considered in CTC enrichment and marker gene selection. When an enrichment of CTCs is done by EpCAM it was recommended, to use a combination of different anti-EpCAM-antibodies, as it was shown, that even different breast cancer cell lines have different EpCAM expression (165). Therefore, it is crucial to regard also EMT-marker genes, as for example lymph node metastases show a strong expression of these genes (166), and a coexpression of EMT-marker genes VIM and Slug is found in patients with CK19-negative CTCs, underlining the importance of focussing on a wider spectrum of marker genes for CTC detection and characterization (167).

A future research topic in the breast cancer CTC-field will be the analysis not only of mRNA but also of miRNA expression profiles by real-time PCR, as well in the primary tumour as in CTCs (168) and also the investigation of plasma DNA (169). Another rather recent finding was, that CTCs might be retained in the microvasculature of the lung in a number of patients with metastatic breast cancer, leading to tumour cell emboli and dyspnoea (170).

Recent developments for CTC detection in ovarian cancer. One of the first approaches to detect CTCs from peripheral blood samples of ovarian cancer patients via real-time PCR was carried out in 2002, using CK7 and CK20 as marker genes. Although tumour cells were detected in some of the analysed blood samples, a conclusion could not be drawn between the incidence of CTCs and clinical and biological significance of these findings (171). A few years later Kallikrein genes six and ten were used for the detection of tumour cells in peripheral blood samples of ovarian cancer patients, but it was seen that the expression of these genes is not strong enough for CTC detection by real-time PCR (172). It is well known, that the presence of CTCs is linked to the occurrence of recurrences and disease-free and overall survival time $(173,174)$ and generally poor clinical outcomes (175). Unlike in breast cancer, the correlation of CTC occurrence before and after chemotherapy was analysed also in ovarian cancer. It was again found, that the presence of CTCs, independent of the time-point of analysis, has no correlation to clinical parameters such as tumour size, grading and tumour histology (176), but is clearly linked to a shorter overall survival (177). Just like in breast cancer studies, also in ovarian cancer a further characterization of CTCs by use of more marker genes, like PPIC, is pursued (178). A rather new topic in the CTC-field in ovarian cancer is the analysis of invasive CTCs (iCTCs), as it was shown that iCTCs are better correlated to progressionfree and overall survival and even more specific than the up to now widely used serum marker CA125 (179). The predictive value of CTC occurrence in ovarian cancer was reconfirmed in 2015 in a study of Zeng et al (180), who was able to demonstrate, that patients with CTCs in the peripheral blood had a shorter DFS and OAS than patients without CTCs in their blood.

Significance of CTCs in cancers of the cervix uteri. CTCs in patients with cervical cancer were already found in 1969, even in patients with 'carcinoma in situ' (181). This was confirmed in 2002, as the presence of CTCs in early stage cervical cancer samples was analysed by real-time PCR using CK19 as marker gene (182). It was concluded, that tumour cell dissemination is one of the early steps in tumour progression. Thereby CTC-detection might also in this cancer entity become an important tool for early estimation of tumour progression (183). The tumour cell retention in the microvasculature of the lung, which is reported for metastatic breast cancer was also shown to occur in cervical carcinomas (170).

CTCs and metastasis in endometrial adenocarcinoma. Up to now there are only a few studies dealing with CTCs in high risk endometrial adenocarcinoma. CTCs were isolated from blood of grade 3 patients and healthy control persons. CTCs were enriched by EpCAM based immunoisolation and analysed by real-time PCR. First, a high plasticity in expression of EMT marker genes ETV5, NOTCH1, SNAI1, TGFB1, 
ZEB1 and ZEB2 could be shown, an association of CTCs with stemness was demonstrated by the expression of ALDH and CD44 and furthermore a potential for therapeutic targets was indicated by the expression of CTNNB1, STS, GDF15, RELA, RUNX1, BRAF and PIK3CA (184). Recently, the presence of CTCs in patients with high-risk endometrial cancer was also reconfirmed (185).

Further potential real-time PCR marker genes in breastcancer and different gynaecological malignancies. Mammaglobin was used as a real-time PCR marker, not only in breast cancer, but in a diversity of gynaecologic malignancies, like malignant tissue from the ovary, uterus and cervix. The expression of h-Mam could not only be detected from blood samples, but also from pleural or peritoneal effusions of cancer patients, while no expression could be detected in control samples from healthy volunteers, thereby making h-Mam a rather useful marker gene for real-time PCR based detection of circulating tumour cells (186). A more recent study aimed at finding a set of marker genes, which could be useful for CTC-detection from a variety of gynaecological malignancies. The six genes CCNE2, MAL2, EMP2, SLC6A8, DKFZp762E1312 and PPIC showed the highest detection rates in primary and recurrent breast, ovarian cancer, endometrial adenocarcinoma, and cervical cancer, and seem thereby to represent a sophisticated marker panel for CTC detection from blood samples of patients with gynaecological malignancies (187).

\section{Conclusion}

Real-time PCR is a highly sensitive method not only for detection, but also for characterization of minimal residual disease from blood samples of patients with epithelial cancer. To further verify the results of real-time PCR in respect to tumour cell quantification, it would be reasonable, to analyse blood samples simultaneously with a gold standard method, for example the CellSearch ${ }^{\circledast}$ system and real-time PCR. Additionally multiplex real-time PCR approaches could also increase the use of this sophisticated technique for tumour diagnostics and therapy monitoring. In a multiplex real-time PCR assay the gene expression of up to 4 genes can be examined simultaneously in only one PCR reaction, meaning, that with a rather small amount of patient material a reasonable detection and a simultaneous characterization of CTCs can be done. The characterization of tumour cells which is possible by real-time PCR approaches will clearly help to refine tumour diagnostics and treatment, as not only the primary tumour can be treated but also these residual tumour cells, which are the origin of distant metastasis. Thereby a future metastasis formation could be prevented or minimized. The CTC characterization could in term contribute to a reduction of side-effects of tumour therapy, increase the efficiency of treatment and lead to a more personalized tumour therapy.

\section{References}

1. Asworth T: A case of cancer in which cells similar to those in the tumours were seen in the blood after death. Australas Med J 14 146-147, 1869.

2. Paget S: The distribution of secondary growths in cancer of the breast. 1889. Cancer Metastasis Rev 8: 98-101, 1989.
3. Fidler IJ: The pathogenesis of cancer metastasis: The 'seed and soil' hypothesis revisited. Nat Rev Cancer 3: 453-458, 2003.

4. Tibbe AG, Miller MC and Terstappen LW: Statistical considerations for enumeration of circulating tumor cells. Cytometry A 71: 154-162, 2007.

5. Park Y, Kitahara T, Urita T, Yoshida Y and Kato R: Expected clinical applications of circulating tumor cells in breast cancer. World J Clin Oncol 2: 303-310, 2011.

6. Balic M, Lin H, Williams A, Datar RH and Cote RJ: Progress in circulating tumor cell capture and analysis: Implications for cancer management. Expert Rev Mol Diagn 12: 303-312, 2012.

7. Allard WJ, Matera J, Miller MC, Repollet M, Connelly MC, Rao C, Tibbe AG, Uhr JW and Terstappen LW: Tumor cells circulate in the peripheral blood of all major carcinomas but not in healthy subjects or patients with nonmalignant diseases. Clin Cancer Res 10: 6897-6904, 2004.

8. Davis JW, Nakanishi H, Kumar VS, Bhadkamkar VA, McCormack R, Fritsche HA, Handy B, Gornet T and Babaian RJ: Circulating tumor cells in peripheral blood samples from patients with increased serum prostate specific antigen: Initial results in early prostate cancer. J Urol 179: 2187-2191, discussion 2191, 2008.

9. Braun S, Vogl FD, Naume B, Janni W, Osborne MP, Coombes RC, Schlimok G, Diel IJ, Gerber B, Gebauer G, et al: A pooled analysis of bone marrow micrometastasis in breast cancer. $\mathrm{N}$ Engl J Med 353: 793-802, 2005.

10. Reinholz MM, Nibbe A, Jonart LM, Kitzmann K, Suman VJ, Ingle JN, Houghton R, Zehentner B, Roche PC and Lingle WL: Evaluation of a panel of tumor markers for molecular detection of circulating cancer cells in women with suspected breast cancer. Clin Cancer Res 11: 3722-3732, 2005.

11. Zieglschmid V, Hollmann C and Böcher O: Detection of disseminated tumor cells in peripheral blood. Crit Rev Clin Lab Sci 42: 155-196, 2005.

12. Parsons HM, Tuttle TM, Kuntz KM, Begun JW, McGovern PM and Virnig BA: Association between lymph node evaluation for colon cancer and node positivity over the past 20 years. JAMA 306: 1089-1097, 2011.

13. Hermanek P, Hutter RV, Sobin LH and Wittekind C: International Union Against Cancer. Classification of isolated tumor cells and micrometastasis. Cancer 86: 2668-2673, 1999.

14. Singletary SE, Patel-Parekh L and Bland KI: Treatment trends in early-stage invasive lobular carcinoma: A report from the National Cancer Data Base. Ann Surg 242: 281-289, 2005.

15. Broersen LH, van Pelt GW, Tollenaar RA and Mesker WE: Clinical application of circulating tumor cells in breast cancer. Cell Oncol (Dordr) 37: 9-15, 2014.

16. Fehm T, Hoffmann O, Aktas B, Becker S, Solomayer EF, Wallwiener D, Kimmig R and Kasimir-Bauer S: Detection and characterization of circulating tumor cells in blood of primary breast cancer patients by RT-PCR and comparison to status of bone marrow disseminated cells. Breast Cancer Res 11: R59, 2009.

17. McShane LM, Hunsberger S and Adjei AA: Effective incorporation of biomarkers into phase II trials. Clin Cancer Res 15: 1898-1905, 2009.

18. Pantel $\mathrm{K}$ and Alix-Panabières $\mathrm{C}$ : Circulating tumour cells in cancer patients: Challenges and perspectives. Trends Mol Med 16: 398-406, 2010.

19. García-Sáenz JA, Martín M, Maestro ML, Vidaurreta M, Veganzones S, Rafael S, Casado A, Bobokova J, Sastre J, De la Orden V, et al: Circulating tumour cells in locally advanced breast cancer. Clin Transl Oncol 11: 544-547, 2009.

20. Lianidou ES and Markou A: Circulating tumor cells as emerging tumor biomarkers in breast cancer. Clin Chem Lab Med 49: 1579-1590, 2011.

21. Fehm T, Müller V, Alix-Panabières $\mathrm{C}$ and Pantel $\mathrm{K}$ : Micrometastatic spread in breast cancer: Detection, molecular characterization and clinical relevance. Breast Cancer Res 10 (Suppl 1): S1, 2008.

22. Lianidou ES and Markou A: Molecular assays for the detection and characterization of CTCs. Recent Results Cancer Res 195: 111-123, 2012.

23. Pantel K and Alix-Panabières C: Detection methods of circulating tumor cells. J Thorac Dis 4: 446-447, 2012.

24. Pantel K and Brakenhoff RH: Dissecting the metastatic cascade. Nat Rev Cancer 4: 448-456, 2004.

25. Uhr JW, Huebschman ML, Frenkel EP, Lane NL, Ashfaq R, Liu H, Rana DR, Cheng L, Lin AT, Hughes GA, et al: Molecular profiling of individual tumor cells by hyperspectral microscopic imaging. Transl Res 159: 366-375, 2012. 
26. Pantel K, Alix-Panabières $\mathrm{C}$ and Riethdorf S: Cancer micrometastases. Nat Rev Clin Oncol 6: 339-351, 2009.

27. Geiger TM and Ricciardi R: Screening options and recommendations for colorectal cancer. Clin Colon Rectal Surg 22: 209-217, 2009.

28. Negin BP and Cohen SJ: Circulating tumor cells in colorectal cancer: Past, present, and future challenges. Curr Treat Options Oncol 11: 1-13, 2010.

29. Kim MY, Oskarsson T, Acharyya S, Nguyen DX, Zhang XH, Norton L and Massagué J: Tumor self-seeding by circulating cancer cells. Cell 139: 1315-1326, 2009.

30. Hayes DC, Secrist H, Bangur CS, Wang T, Zhang X, Harlan D, Goodman GE, Houghton RL, Persing DH and Zehentner BK: Multigene real-time PCR detection of circulating tumor cells in peripheral blood of lung cancer patients. Anticancer Res 26 (2B): $1567-1575,2006$

31. Saloustros E and Mavroudis D: CTCs in primary breast cancer (II). Recent Results Cancer Res 195: 187-192, 2012.

32. Stathopoulou A, Gizi A, Perraki M, Apostolaki S, Malamos N, Mavroudis D, Georgoulias V and Lianidou ES: Real-time quantification of CK-19 mRNA-positive cells in peripheral blood of breast cancer patients using the lightcycler system. Clin Cancer Res 9: 5145-5151, 2003.

33. Schoenfeld A, Kruger KH, Gomm J, Sinnett HD, Gazet JC, Sacks N, Bender HG, Luqmani Y and Coombes RC: The detection of micrometastases in the peripheral blood and bone marrow of patients with breast cancer using immunohistochemistry and reverse transcriptase polymerase chain reaction for keratin 19. Eur J Cancer 33: 854-861, 1997.

34. Ignatiadis M, Xenidis N, Perraki M, Apostolaki S, Politaki E, Kafousi M, Stathopoulos EN, Stathopoulou A, Lianidou E, Chlouverakis G, et al: Different prognostic value of cytokeratin-19 mRNA positive circulating tumor cells according to estrogen receptor and HER2 status in early-stage breast cancer. J Clin Oncol 25: 5194-5202, 2007.

35. Xenidis N, Perraki M, Kafousi M, Apostolaki S, Bolonaki I, Stathopoulou A, Kalbakis K, Androulakis N, Kouroussis C Pallis T, et al: Predictive and prognostic value of peripheral blood cytokeratin-19 mRNA-positive cells detected by real-time polymerase chain reaction in node-negative breast cancer patients. J Clin Oncol 24: 3756-3762, 2006

36. Xenidis N, Ignatiadis M, Apostolaki S, Perraki M, Kalbakis K, Agelaki S, Stathopoulos EN, Chlouverakis G, Lianidou E, Kakolyris S, et al: Cytokeratin-19 mRNA-positive circulating tumor cells after adjuvant chemotherapy in patients with early breast cancer. J Clin Oncol 27: 2177-2184, 2009.

37. Sotiriou C and Pusztai L: Gene-expression signatures in breast cancer. N Engl J Med 360: 790-800, 2009.

38. Xenidis N, Markos V, Apostolaki S, Perraki M, Pallis A, Sfakiotaki G, Papadatos-Pastos D, Kalmanti L, Kafousi M, Stathopoulos E, et al: Clinical relevance of circulating CK-19 mRNA-positive cells detected during the adjuvant tamoxifen treatment in patients with early breast cancer. Ann Oncol 18 : 1623-1631, 2007.

39. Saloustros E, Perraki M, Apostolaki S, Kallergi G, Xyrafas A, Kalbakis K, Agelaki S, Kalykaki A, Georgoulias V and Mavroudis D: Cytokeratin-19 mRNA-positive circulating tumor cells during follow-up of patients with operable breast cancer: Prognostic relevance for late relapse. Breast Cancer Res 13: R60, 2011.

40. Alix-Panabières $\mathrm{C}$ and Pantel $\mathrm{K}$ : Circulating tumor cells: Liquid biopsy of cancer. Clin Chem 59: 110-118, 2013.

41. Saucedo-Zeni N, Mewes S, Niestroj R, Gasiorowski L, Murawa D, Nowaczyk P, Tomasi T, Weber E, Dworacki G, Morgenthaler NG, et al: A novel method for the in vivo isolation of circulating tumor cells from peripheral blood of cancer patients using a functionalized and structured medical wire. Int J Oncol 41: 1241-1250, 2012.

42. Sleijfer S, Gratama JW, Sieuwerts AM, Kraan J, Martens JW and Foekens JA: Circulating tumour cell detection on its way to routine diagnostic implementation? Eur J Cancer 43: 2645-2650, 2007.

43. Fehm T, Solomayer EF, Meng S, Tucker T, Lane N, Wang J and Gebauer G: Methods for isolating circulating epithelial cells and criteria for their classification as carcinoma cells. Cytotherapy 7: 171-185, 2005

44. Königsberg R, Obermayr E, Bises G, Pfeiler G, Gneist M, Wrba F, de Santis M,Zeillinger R, Hudec M and Dittrich C: Detection of EpCAM positive and negative circulating tumor cells in metastatic breast cancer patients. Acta Oncol 50: 700-710, 2011.
45. Sieuwerts AM, Kraan J, Bolt-de Vries J, van der Spoel P, Mostert B, Martens JW, Gratama JW, Sleijfer S and Foekens JA: Molecular characterization of circulating tumor cells in large quantities of contaminating leukocytes by a multiplex real-time PCR. Breast Cancer Res Treat 118: 455-468, 2009.

46. Schindlbeck C, Stellwagen J, Jeschke U, Karsten U, Rack B, Janni W, Jückstock J, Tulusan A, Sommer H and Friese K: Immunomagnetic enrichment of disseminated tumor cells in bone marrow and blood of breast cancer patients by the ThomsenFriedenreich-Antigen. Clin Exp Metastasis 25: 233-240, 2008.

47. Vona G, Sabile A, Louha M, Sitruk V, Romana S, Schütze K, Capron F, Franco D, Pazzagli M, Vekemans M, et al: Isolation by size of epithelial tumor cells : A new method for the immunomorphological and molecular characterization of circulatingtumor cells. Am J Pathol 156: 57-63, 2000.

48. Busch R, Cesar D, Higuera-Alhino D, Gee T, Hellerstein MK and McCune JM: Isolation of peripheral blood $\mathrm{CD}^{+} \mathrm{T}$ cells using RosetteSep and MACS for studies of DNA turnover by deuterium labeling. J Immunol Methods 286: 97-109, 2004.

49. Hayes DF and Smerage JB: Circulating tumor cells. Prog Mol Biol Transl Sci 95: 95-112, 2010.

50. Riethdorf S, Fritsche H, Müller V, Rau T, Schindlbeck C, Rack B, Janni W, Coith C, Beck K, Jänicke F, et al: Detection of circulating tumor cells in peripheral blood of patients with metastatic breast cancer: A validation study of the CellSearch system. Clin Cancer Res 13: 920-928, 2007.

51. Cristofanilli M: The biological information obtainable from circulating tumor cells. Breast 18 (Suppl 3): S38-S40, 2009.

52. Cristofanilli M, Budd GT, Ellis MJ, Stopeck A, Matera J, Miller MC, Reuben JM, Doyle GV, Allard WJ, Terstappen LW, et al: Circulating tumor cells, disease progression, and survival in metastatic breast cancer. N Engl J Med 351: 781-791, 2004.

53 Nolé F, Munzone E, Zorzino L, Minchella I, Salvatici M, Botteri E, Medici M, Verri E, Adamoli L, Rotmensz N, et al: Variation of circulating tumor cell levels during treatment of metastatic breast cancer: Prognostic and therapeutic implications. Ann Oncol 19: 891-897, 2008.

54. Bidard FC, Mathiot C, Delaloge S, Brain E, Giachetti S, de Cremoux P, Marty M and Pierga JY: Single circulating tumor cell detection and overall survival in nonmetastatic breast cancer. Ann Oncol 21: 729-733, 2010.

55. Botteri E, Sandri MT, Bagnardi V, Munzone E, Zorzino L, Rotmensz N, Casadio C, Cassatella MC, Esposito A,Curigliano G, et al: Modeling the relationship between circulating tumour cells number and prognosis of metastatic breast cancer. Breast Cancer Res Treat 122: 211-217, 2010

56. Jakob C, Aust DE, Liebscher B, Baretton GB, Datta K and Muders MH: Lymphangiogenesis in regional lymph nodes is an independent prognostic marker in rectal cancer patients after neoadjuvant treatment. PLoS One 6: e27402, 2011.

57. Miller MC, Doyle GV and Terstappen LW: Significance of circulating tumor cells detected by the CellSearch system in patients with metastatic breast colorectal and prostate cancer. J Oncol 2010: 617421, 2010.

58. Farace F, Massard C, Vimond N, Drusch F, Jacques N, Billiot F, Laplanche A, Chauchereau A, Lacroix L, Planchard D, et al: A direct comparison of CellSearch and ISET for circulating tumour-cell detection in patients with metastatic carcinomas. $\mathrm{Br}$ J Cancer 105: 847-853, 2011.

59. Alix-Panabières C: EPISPOT assay: Detection of viable DTCs/ CTCs in solid tumor patients. Recent Results Cancer Res 195: 69-76, 2012.

60. Alix-Panabières C, Vendrell JP, Pellé O, Rebillard X, Riethdorf S, Müller V, Fabbro M and Pantel K: Detection and characterization of putative metastatic precursor cells in cancer patients. Clin Chem 53: 537-539, 2007

61. Hanahan D and Weinberg RA: Hallmarks of cancer: The next generation. Cell 144: 646-674, 2011

62. Somlo G, Lau SK, Frankel P, Hsieh HB, Liu X, Yang L, Krivacic R and Bruce RH: Multiple biomarker expression on circulating tumor cells in comparison to tumor tissues from primary and metastatic sites in patients with locally advanced/inflammatory, and stage IV breast cancer, using a novel detection technology. Breast Cancer Res Treat 128: 155-163, 2011.

63. Alix-Panabières C, Vendrell JP, Slijper M, Pellé O, Barbotte E, Mercier G, Jacot W, Fabbro M and Pantel K: Full-length cytokeratin-19 is released by human tumor cells: A potential role in metastatic progression of breast cancer. Breast Cancer Res 11: R39, 2009. 
64. Fehm T, Sagalowsky A, Clifford E, Beitsch P, Saboorian H, Euhus D, Meng S, Morrison L, Tucker T, Lane N, et al: Cytogenetic evidence that circulating epithelial cells in patients with carcinoma are malignant. Clin Cancer Res 8: 2073-2084, 2002.

65. Swennenhuis JF, Tibbe AG, Levink R, Sipkema RC and Terstappen LW: Characterization of circulating tumor cells by fluorescence in situ hybridization. Cytometry A 75: 520-527, 2009.

66. Bartels CL and Tsongalis GJ: MicroRNAs: Novel biomarkers for human cancer. Clin Chem 55: 623-631, 2009.

67. Issadore D, Chung J, Shao H, Liong M, Ghazani AA, Castro CM, Weissleder $\mathrm{R}$ and Lee $\mathrm{H}$ : Ultrasensitive clinical enumeration of rare cells ex vivo using a micro-hall detector. Sci Transl Med 4: 141ra92, 2012.

68. Nagrath S, Sequist LV, Maheswaran S, Bell DW, Irimia D, Ulkus L, Smith MR, Kwak EL, Digumarthy S, Muzikansky A, et al: Isolation of rare circulating tumour cells in cancer patients by microchip technology. Nature 450: 1235-1239, 2007.

69. Stott SL, Hsu CH, Tsukrov DI, Yu M, Miyamoto DT, Waltman BA, Rothenberg SM, Shah AM, Smas ME, Korir GK, et al: Isolation of circulating tumor cells using a microvortexgenerating herringbone-chip. Proc Natl Acad Sci USA 107: 18392-18397, 2010.

70. Sun YY, Lu M, Xi XW, Qiao QQ, Chen LL, Xu XM and Feng YJ: Regulation of epithelial-mesenchymal transition by homeobox gene DLX4 in JEG-3 trophoblast cells: A role in preeclampsia. Reprod Sci 18: 1138-1145, 2011.

71. Wang X, Qian X, Beitler JJ, Chen ZG, Khuri FR, Lewis MM, Shin HJ, Nie S and Shin DM: Detection of circulating tumor cells in human peripheral blood using surface-enhanced Raman scattering nanoparticles. Cancer Res 71: 1526-1532, 2011.

72. Deng G, Herrler M, Burgess D, Manna E, Krag D and Burke JF: Enrichment with anti-cytokeratin alone or combined with anti-EpCAM antibodies significantly increases the sensitivity for circulating tumor cell detection in metastatic breast cancer patients. Breast Cancer Res 10: R69, 2008

73. Wang L, Wang Y, Liu Y, Cheng M, Wu X and Wei H: Flow cytometric analysis of CK19 expression in the peripheral blood of breast carcinoma patients: Relevance for circulating tumor cell detection. J Exp Clin Cancer Res 28: 57, 2009.

74. Bustin SA and Mueller R: Real-time reverse transcription PCR (qRT-PCR) and its potential use in clinical diagnosis. Clin Sci (Lond) 109: 365-379, 2005.

75. Dubois V, Delort L, Mishellany F, Jarde T, Billard H, Lequeux C, Damour O, Penault-Llorca F, Vasson MP and Caldefie-Chezet F: Zinc-alpha2-glycoprotein: A new biomarker of breast cancer? Anticancer Res 30: 2919-2925, 2010.

76. Fabisiewicz A, Kulik J, Kober P, Brewczyńska E, Pieńkowski T and Siedlecki JA: Detection of circulating breast cancer cells in peripheral blood by a two-marker reverse transcriptasepolymerase chain reaction assay. Acta Biochim Pol 51: 747-755, 2004.

77. Ring A, Smith IE and Dowsett M: Circulating tumour cells in breast cancer. Lancet Oncol 5: 79-88, 2004.

78. Van der Auwera I, Peeters D, Benoy IH, Elst HJ, Van Laere SJ, Prové A, Maes H, Huget P, van Dam P, Vermeulen PB, et al: Circulating tumour cell detection: A direct comparison between the CellSearch System, the AdnaTest and CK-19/mammaglobin RT-PCR in patients with metastatic breast cancer. Br J Cancer 102: 276-284, 2010.

79. Gibson UE, Heid CA and Williams PM: A novel method for real time quantitative RT-PCR. Genome Res 6: 995-1001, 1996.

80. Bustin SA: Absolute quantification of mRNA using real-time reverse transcription polymerase chain reaction assays. J Mol Endocrinol 25: 169-193, 2000.

81. Ginzinger DG: Gene quantification using real-time quantitative PCR: An emerging technology hits the mainstream. Exp Hematol 30: 503-512, 2002.

82. Wittwer CT, Herrmann MG, Moss AA and Rasmussen RP. Continuous fluorescence monitoring of rapid cycle DNA amplification. Biotechniques 22: 130-131, 134-138, 1997.

83. Ke LD, Chen Z and Yung WK: A reliability test of standardbased quantitative PCR: Exogenous vs endogenous standards Mol Cell Probes 14: 127-135, 2000.

84. Vandesompele J, De Preter K, Pattyn F, Poppe B, Van Roy N, De Paepe A and Speleman F: Accurate normalization of real-time quantitative RT-PCR data by geometric averaging of multiple internal control genes. Genome Biol 3: Research0034, 2002.
85. Pfaffl MW, Lange IG, Daxenberger A and Meyer $\mathrm{HH}$ Tissue-specific expression pattern of estrogen receptors (ER): Quantification of ER alpha and ER beta mRNA with real-time RT-PCR. APMIS 109: 345-355, 2001.

86. Hocquette JF and Brandstetter AM: Common practice in molecular biology may introduce statistical bias and misleading biological interpretation. J Nutr Biochem 13: 370-377, 2002.

87. Ririe KM, Rasmussen RP and Wittwer CT: Product differentiation by analysis of DNA melting curves during the polymerase chain reaction. Anal Biochem 245: 154-160, 1997.

88. Elnifro EM, Ashshi AM, Cooper RJ and Klapper PE: Multiplex PCR: Optimization and application in diagnostic virology. Clin Microbiol Rev 13: 559-570, 2000.

89. Max N, Wolf K, Thiel E and Keilholz U: Quantitative nested real-time RT-PCR specific for tyrosinase transcripts to quantitate minimal residual disease. Clin Chim Acta 317: 39-46, 2002.

90. Halford WP: The essential prerequisites for quantitative RT-PCR. Nat Biotechnol 17: 835, 1999.

91. Orlando C, Pinzani P and Pazzagli M: Developments in quantitative PCR. Clin Chem Lab Med 36: 255-269, 1998.

92. Ghossein RA, Carusone L and Bhattacharya S: Molecular detection of micrometastases and circulating tumor cells in melanoma prostatic and breast carcinomas. In Vivo 14: 237-250, 2000.

93. Cone RW, Hobson AC and Huang ML: Coamplified positive control detects inhibition of polymerase chain reactions. J Clin Microbiol 30: 3185-3189, 1992.

94. Gerges N, Rak J and Jabado N: New technologies for the detection of circulating tumour cells. Br Med Bull 94: 49-64, 2010.

95. Chen TF, Jiang GL, Fu XL, Wang LJ, Qian H, Wu KL and Zhao S: CK19 mRNA expression measured by reverse-transcription polymerase chain reaction (RT-PCR) in the peripheral blood of patients with non-small cell lung cancer treated by chemoradiation: An independent prognostic factor. Lung Cancer 56: 105-114, 2007.

96. Lambrechts AC, Bosma AJ, Klaver SG, Top B, Perebolte L, van' t Veer LJ and Rodenhuis S: Comparison of immunocytochemistry, reverse transcriptase polymerase chain reaction, and nucleic acid sequence-based amplification for the detection of circulating breast cancer cells. Breast Cancer Res Treat 56: 219-231, 1999.

97. Lianidou ES and Markou A: Circulating tumor cells in breast cancer: Detection systems, molecular characterization, and future challenges. Clin Chem 57: 1242-1255, 2011.

98. Pantel K, Brakenhoff RH and Brandt B: Detection, clinical relevance and specific biological properties of disseminating tumour cells. Nat Rev Cancer 8: 329-340, 2008.

99. Gabert J, Beillard E, van der Velden VH, Bi W, Grimwade D, Pallisgaard N, Barbany G, Cazzaniga G, Cayuela JM, Cavé H, et al: Standardization and quality control studies of 'real-time' quantitative reverse transcriptase polymerase chain reaction of fusion gene transcripts for residual disease detection in leukemia - a Europe Against Cancer program. Leukemia 17: 2318-2357, 2003.

100. Müller V, Witzel I, Lück HJ, Köhler G, von Minckwitz G, Möbus V, Sattler D, Wilczak W, Löning T, Jänicke F, et al: Prognostic and predictive impact of the HER-2/ neu extracellular domain (ECD) in the serum of patients treated with chemotherapy for metastatic breast cancer. Breast Cancer Res Treat 86: 9-18, 2004.

101. Niesters HG: Standardization and quality control in molecular diagnostics. Expert Rev Mol Diagn 1: 129-131, 2001.

102. Niesters HG and Puchhammer-Stöckl E: Standardisation and controls, why can't we overcome the hurdles? J Clin Virol 31: 81-83, 2004.

103. Raengsakulrach B, Nisalak A, Maneekarn N, Yenchitsomanus PT, Limsomwong C, Jairungsri A, Thirawuth V, Green S, Kalayanarooj S, Suntayakorn S, et al: Comparison of four reverse transcription-polymerase chain reaction procedures for the detection of dengue virus in clinical specimens. J Virol Methods 105: 219-232, 2002.

104. Mostert B, Sleijfer S, Foekens JA and Gratama JW: Circulating tumor cells (CTCs): Detection methods and their clinical relevance in breast cancer. Cancer Treat Rev 35: 463-474, 2009.

105. Paterlini-Brechot P and Benali NL: Circulating tumor cells (CTC) detection: Clinical impact and future directions. Cancer Lett 253: 180-204, 2007. 
106. Aktas B, Tewes M, Fehm T, Hauch S, Kimmig R and KasimirBauer S: Stem cell and epithelial-mesenchymal transition markers are frequently overexpressed in circulating tumor cells of metastatic breast cancer patients. Breast Cancer Res 11: R46, 2009.

107. Ignatiadis M, Kallergi G, Ntoulia M, Perraki M, Apostolaki S, Kafousi M, Chlouverakis G, Stathopoulos E, Lianidou E, Georgoulias V, et al: Prognostic value of the molecular detection of circulating tumor cells using a multimarker reverse transcription-PCR assay for cytokeratin 19, mammaglobin A, and HER2 in early breast cancer. Clin Cancer Res 14: 2593-2600, 2008.

108. Kowalewska M, Chechlińska M, Markowicz S, Kober P and Nowak R: The relevance of RT-PCR detection of disseminated tumour cells is hampered by the expression of markers regarded as tumour-specific in activated lymphocytes. Eur J Cancer 42: 2671-2674, 2006.

109. Suchy B, Austrup F, Driesel G, Eder C, Kusiak I, Uciechowski P, Grill HJ and Giesing M: Detection of mammaglobin expressing cells in blood of breast cancer patients. Cancer Lett 158: 171-178, 2000.

110. Jiang Y, Harlocker SL, Molesh DA, Dillon DC, Stolk JA, Houghton RL, Repasky EA, Badaro R, Reed SG and Xu J: Discovery of differentially expressed genes in human breast cancer using subtracted cDNA libraries and cDNA microarrays. Oncogene 21: 2270-2282, 2002.

111. Ignatiadis M, Perraki M, Apostolaki S, Politaki E, Xenidis N, Kafousi M, Stathopoulos E, Lianidou E, Sotiriou C, Georgoulias V, et al: Molecular detection and prognostic value of circulating cytokeratin-19 messenger RNA-positive and HER2 messenger RNA-positive cells in the peripheral blood of women with early-stage breast cancer. Clin Breast Cancer 7: 883-889, 2007.

112. Slade MJ, Smith BM, Sinnett HD, Cross NC and Coombes RC: Quantitative polymerase chain reaction for the detection of micrometastases in patients with breast cancer. J Clin Oncol 17: 870-879, 1999.

113. Stathopoulou A, Mavroudis D, Perraki M, Apostolaki S, Vlachonikolis I, Lianidou E and Georgoulias V: Molecular detection of cancer cells in the peripheral blood of patients with breast cancer: Comparison of CK-19, CEA and maspin as detection markers. Anticancer Res 23 (2C): 1883-1890, 2003.

114. Stathopoulou A, Ntoulia M, Perraki M, Apostolaki S, Mavroudis D, Malamos N, Georgoulias V and Lianidou ES: A highly specific real-time RT-PCR method for the quantitative determination of CK-19 mRNA positive cells in peripheral blood of patients with operable breast cancer. Int J Cancer 119: 1654-1659, 2006.

115. Silva HA, Abraúl E, Raimundo D, Dias MF, Marques C, Guerra C, de Oliveira CF and Regateiro FJ: Molecular detection of EGFRvIII-positive cells in the peripheral blood of breast cancer patients. Eur J Cancer 42: 2617-2622, 2006.

116. Gargano G, Agnese V, Calò V, Corsale S, Augello C, Bruno L, La Paglia L, Gullo A, Ottini L, Russo A, et al; Gruppo Oncologico dell'Italia Meridionale: Detection and quantification of mammaglobin in the blood of breast cancer patients: Can it be useful as a potential clinical marker? Preliminary results of a GOIM (Gruppo Oncologico dell'Italia Meridionale) prospective study. Ann Oncol 17 (Suppl 7): vii41-vii45, 2006.

117. Mercatali L, Valenti V, Calistri D, Calpona S, Rosti G, Folli S, Gaudio M, Frassineti GL, Amadori D and Flamini E: RT-PCR determination of maspin and mammaglobin $\mathrm{B}$ in peripheral blood of healthy donors and breast cancer patients. Ann Oncol 17: 424-428, 2006.

118. Ntoulia M, Stathopoulou A, Ignatiadis M, Malamos N, Mavroudis D, Georgoulias V and Lianidou ES: Detection of Mammaglobin A-mRNA-positive circulating tumor cells in peripheral blood of patients with operable breast cancer with nested RT-PCR. Clin Biochem 39: 879-887, 2006.

119. Fantl V, Smith R, Brookes S, Dickson C and Peters G: Chromosome 11q13 abnormalities in human breast cancer. Cancer Surv 18: 77-94, 1993.

120. Fleming TP and Watson MA: Mammaglobin, a breast-specific gene, and its utility as a marker for breast cancer. Ann NY Acad Sci 923: 78-89, 2000

121. Ceballos MP, Zumoffen C, Massa E, Cipulli G, Funes CC, Gil AB, Morales C, Tozzini R and Ghersevich S: Detection of mammaglogin A in blood from breast cancer patients, before and after treatment, using a one-tube nested PCR protocol. Association with the absence of tumor estrogen receptors. Clin Biochem 44: 1429-1433, 2011
122. Corradini P, Voena C, Astolfi M, Delloro S, Pilotti S, Arrigoni G, Bregni M, Pileri A and Gianni AM: Maspin and mammaglobin genes are specific markers for RT-PCR detection of minimal residual disease in patients with breast cancer. Ann Oncol 12: 1693-1698, 2001.

123. Ferro P, Franceschini MC, Bacigalupo B, Dessanti P, Falco E, Fontana V, Gianquinto D, Pistillo MP, Fedeli F and Roncella S: Detection of circulating tumour cells in breast cancer patients using human mammaglobin RT-PCR: Association with clinical prognostic factors. Anticancer Res 30: 2377-2382, 2010.

124. Roncella S, Ferro P, Bacigalupo B, Pronzato P, Tognoni A, Falco E, Gianquinto D, Ansaldo V, Dessanti P, Fais F, et al: Human mammaglobin mRNA is a reliable molecular marker for detecting occult breast cancer cells in peripheral blood. J Exp Clin Cancer Res 24: 265-271, 2005.

125. Silva AL, Tomé MJ, Correia AE and Passos-Coelho JL: Human mammaglobin RT-PCR assay for detection of occult breast cancer cells in hematopoietic products. Ann Oncol 13: 422-429, 2002.

126. Ballestrero A, Garuti A, Bertolotto M, Rocco I, Boy D, Nencioni A, Ottonello L and Patrone F: Effect of different cytokines on mammaglobin and maspin gene expression in normal leukocytes: Possible relevance to the assays for the detection of micrometastatic breast cancer. Br J Cancer 92: 1948-1952, 2005.

127. Cerveira N, Torres L, Rocha P, Bizarro S, Pereira D, Abreu J, Henrique R, Teixeira MR and Castedo S: Highly sensitive detection of the MGB1 transcript (mammaglobin) in the peripheral blood of breast cancer patients. Int J Cancer 108: 592-595, 2004.

128. Zach O, Kasparu H, Krieger O, Hehenwarter W, Girschikofsky M and Lutz D: Detection of circulating mammary carcinoma cells in the peripheral blood of breast cancer patients via a nested reverse transcriptase polymerase chain reaction assay for mammaglobin mRNA. J Clin Oncol 17: 2015-2019, 1999.

129. Silva JM, Domínguez G, González-Sancho JM, García JM, Silva J, García-Andrade C, Navarro A, Muñoz A and Bonilla F: Expression of thyroid hormone receptor/erbA genes is altered in human breast cancer. Oncogene 21: 4307-4316, 2002.

130. Tewes M, Aktas B, Welt A, Mueller S, Hauch S, Kimmig R and Kasimir-Bauer S: Molecular profiling and predictive value of circulating tumor cells in patients with metastatic breast cancer: An option for monitoring response to breast cancer related therapies. Breast Cancer Res Treat 115: 581-590, 2009.

131. Shen C, Hu L, Xia L and Li Y: The detection of circulating tumor cells of breast cancer patients by using multimarker (Survivin, hTERT and hMAM) quantitative real-time PCR. Clin Biochem 42: 194-200, 2009.

132. Zehentner BK, Persing DH, Deme A, Toure P, Hawes SE, Brooks L, Feng Q, Hayes DC, Critichlow CW, Houghton RL, et al: Mammaglobin as a novel breast cancer biomarker: Multigene reverse transcription-PCR assay and sandwich ELISA. Clin Chem 50: 2069-2076, 2004.

133. Barrallo-Gimeno A and Nieto MA: The Snail genes as inducers of cell movement and survival: Implications in development and cancer. Development 132: 3151-3161, 2005.

134. Monteiro J and Fodde R: Cancer stemness and metastasis: Therapeutic consequences and perspectives. Eur J Cancer 46 1198-1203, 2010.

135. Sabbah M,Emami S, Redeuilh G, Julien S, Prévost G, Zimber A, Ouelaa R, Bracke M, De Wever O and Gespach C: Molecular signature and therapeutic perspective of the epithelial-to-mesenchymal transitions in epithelial cancers. Drug Resist Updat 11: 123-151, 2008

136. Thompson R: Cancer: Epithelial subtype influences the prognosis of invasive IPMN. Nat Rev Gastroenterol Hepatol 8: $420,2011$.

137. Gradilone A, Raimondi C, Nicolazzo C, Petracca A, Gandini O, Vincenzi B, Naso G, Aglianò AM, Cortesi E and Gazzaniga P: Circulating tumour cells lacking cytokeratin in breast cancer: The importance of being mesenchymal. J Cell Mol Med 15: 1066-1070, 2011.

138. Bednarz-Knoll N, Alix-Panabières C and Pantel K: Plasticity of disseminating cancer cells in patients with epithelial malignancies. Cancer Metastasis Rev 31: 673-687, 2012.

139. Smirnov DA, Zweitzig DR, Foulk BW, Miller MC, Doyle GV, Pienta KJ, Meropol NJ, Weiner LM, Cohen SJ, Moreno JG, et al: Global gene expression profiling of circulating tumor cells. Cancer Res 65: 4993-4997, 2005. 
140. de Albuquerque A, Kaul S, Breier G, Krabisch P and Fersis N: Multimarker analysis of circulating tumor cells in peripheral blood of metastatic breast cancer patients: A step forward in personalized medicine. Breast Care (Basel) 7: 7-12, 2012.

141. Lowes LE and Allan AL: Recent advances in the molecular characterization of circulating tumor cells. Cancers (Basel) 6: 595-624, 2014.

142. Grover PK, Cummins AG, Price TJ, Roberts-Thomson IC and Hardingham JE: Circulating tumour cells: The evolving concept and the inadequacy of their enrichment by EpCAM-based methodology for basic and clinical cancer research. Ann Oncol 25: 1506-1516, 2014

143. Liu X and Fan D: The epithelial-mesenchymal transition and cancer stem cells: Functional and mechanistic links. Curr Pharm Des 21: 1279-1291, 2014.

144. Cabiňaková $M$ and Tesařová $P$ : Disseminated and circulating tumour cells and their role in breast cancer. Folia Biol (Praha) 58: 87-97, 2012

145. Daskalaki A, Agelaki S, Perraki M, Apostolaki S, Xenidis N, Stathopoulos E, Kontopodis E, Hatzidaki D, Mavroudis D and Georgoulias V: Detection of cytokeratin-19 mRNA-positive cells in the peripheral blood and bone marrow of patients with operable breast cancer. Br J Cancer 101: 589-597, 2009.

146. Andergassen U, Hofmann S, Kölbl AC, Schindlbeck C Neugebauer J, Hutter S, Engelstädter V, Ilmer M, Friese K and Jeschke U: Detection of tumor cell-specific mRNA in the peripheral blood of patients with breast cancer-evaluation of several markers with real-time reverse transcription-PCR. Int J Mol Sci 14: 1093-1104, 2013.

147. Cierna Z, Mego M, Janega P, Karaba M, Minarik G, Benca J, Sedlácková T, Cingelova S, Gronesova P, Manasova D, et al: Matrix metalloproteinase 1 and circulating tumor cells in early breast cancer. BMC Cancer 14: 472, 2014.

148. Cheng M, Chen Y, Zou D, Shen G, Bian G, Shen G and Hu S: The clinical utility of circulating tumor cells in breast cancer patients: Detection by a quantitative assay of h-MAM gene expression. Int J Biol Markers 29: e268-e278, 2014.

149. Xi L, Nicastri DG, El-Hefnawy T, Hughes SJ, Luketich JD and Godfrey TE: Optimal markers for real-time quantitative reverse transcription PCR detection of circulating tumor cells from melanoma, breast, colon, esophageal, head and neck, and lung cancers. Clin Chem 53: 1206-1215, 2007.

150. Lasa A, Garcia A, Alonso C, Millet P, Cornet M, Ramón y Cajal T, Baiget $\mathrm{M}$ and Barnadas A: Molecular detection of peripheral blood breast cancer mRNA transcripts as a surrogate biomarker for circulating tumor cells. PLoS One 8: e74079, 2013.

151. Skondra M, Gkioka E, Kostakis ID, Pissimissis N, Lembessis P, Pectasides D and Koutsilieris M: Detection of circulating tumor cells in breast cancer patients using multiplex reverse transcription-polymerase chain reaction and specific primers for MGB, PTHRP and KRT19 correlation with clinicopathological features. Anticancer Res 34: 6691-6699, 2014

152. Zebisch M, Kölbl AC, Schindlbeck C, Neugebauer J, Heublein S, Ilmer M, Rack B, Friese K, Jeschke U and Andergassen U: Quantification of breast cancer cells in peripheral blood samples by real-time RT-PCR. Anticancer Res 32: 5387-5391, 2012.

153. Guo M, Li X, Zhang S, Song H, Zhang W, Shang X, Zheng Y, Jiang H, Lv Q, Jiang Y, et al: Real-time quantitative RT-PCR detection of circulating tumor cells from breast cancer patients. Int J Oncol 46: 281-289, 2015.

154. Pinzani P, Salvadori B, Simi L, Bianchi S, Distante V, Cataliotti L, Pazzagli M and Orlando C: Isolation by size of epithelial tumor cells in peripheral blood of patients with breast cancer: Correlation with real-time reverse transcriptasepolymerase chain reaction results and feasibility of molecular analysis by laser microdissection. Hum Pathol 37: 711-718, 2006

155. Nakagawa T, Martinez SR, Goto Y, Koyanagi K, Kitago M, Shingai T, Elashoff DA, Ye X, Singer FR, Giuliano AE, et al: Detection of circulating tumor cells in early-stage breast cancer metastasis to axillary lymph nodes. Clin Cancer Res 13: 4105-4110, 2007.

156. Zhang L, Ridgway LD, Wetzel MD, Ngo J, Yin W, Kumar D, Goodman JC, Groves MD and Marchetti D: The identification and characterization of breast cancer CTCs competent for brain metastasis. Sci Transl Med 5: 180ra48, 2013.
157. Androulakis N, Agelaki S, Perraki M, Apostolaki S, Bozionelou V, Pallis A, Kalbakis K, Xyrafas A, Mavroudis D and Georgoulias V: Clinical relevance of circulating CK-19mRNApositive tumour cells before front-line treatment in patients with metastatic breast cancer. Br J Cancer 106: 1917-1925, 2012.

158. Georgoulias V, Apostolaki S, Bozionelou V, Politaki E, Perraki M, Georgoulia N, Kalbakis K, Kotsakis A, Xyrafas A, Agelaki S, et al: Effect of front-line chemotherapy on circulating CK-19 mRNA-positive cells in patients with metastatic breast cancer. Cancer Chemother Pharmacol 74: 1217-1225, 2014.

159. Xenidis N, Perraki M, Apostolaki S, Agelaki S, Kalbakis K, Vardakis N, Kalykaki A, Xyrafas A, Kakolyris S, Mavroudis D, et al: Differential effect of adjuvant taxane-based and taxanefree chemotherapy regimens on the CK-19 mRNA-positive circulating tumour cells in patients with early breast cancer. $\mathrm{Br}$ J Cancer 108: 549-556, 2013.

160. Wang HY, Ahn S, Kim S, Park S, Park S, Han H, Sohn JH, Kim S and Lee H: Detection of circulating tumor cells in patients with breast cancer using the quantitative RT-PCR assay for monitoring of therapy efficacy. Exp Mol Pathol 97: 445-452, 2014.

161. Ušiaková Z, Mikulová V, Pintérová D, Brychta M, Valcháŕ J, Kubecová M, Tesařová $\mathrm{P}$, Bobek $\mathrm{V}$ and Kološtová K: Circulating tumor cells in patients with breast cancer: Monitoring chemotherapy success. In Vivo 28: 605-614, 2014

162. Mikulová V, Cabiňaková M, Janatková I, Mestek O, Zima T and Tesařová $P$ : Detection of circulating tumor cells during follow-up of patients with early breast cancer: Clinical utility for monitoring of therapy efficacy. Scand J Clin Lab Invest 74: 132-142, 2014.

163. Mego M, Mani SA, Lee BN, Li C, Evans KW, Cohen EN, Gao H, Jackson SA, Giordano A, Hortobagyi GN, et al: Expression of epithelial-mesenchymal transition-inducing transcription factors in primary breast cancer: The effect of neoadjuvant therapy. Int J Cancer 130: 808-816, 2012.

164. Baccelli I, Stenzinger A, Vogel V, Pfitzner BM, Klein C, Wallwiener M, Scharpff M, Saini M, Holland-Letz T, Sinn HP, et al: Co-expression of MET and CD47 is a novel prognosticator for survival of luminal breast cancer patients. Oncotarget 5: $8147-8160,2014$.

165. Sterzynska K, Kempisty B, Zawierucha P and Zabel M: Analysis of the specificity and selectivity of anti-EpCAM antibodies in breast cancer cell lines. Folia Histochem Cytobiol 50: 534-541, 2012.

166. Markiewicz A, Książkiewicz M, Seroczyńska B, Skokowski J, Szade J, Wełnicka-Jaśkiewicz M and Zaczek AJ: Heterogeneity of mesenchymal markers expression-molecular profiles of cancer cells disseminated by lymphatic and hematogenous routes in breast cancer. Cancers (Basel) 5: 1485-1503, 2013.

167. Serrano MJ, Ortega FG, Alvarez-Cubero MJ, Nadal R, Sanchez-Rovira P, Salido M, Rodríguez M, García-Puche JL, Delgado-Rodriguez M, Solé F, et al: EMT and EGFR in CTCs cytokeratin negative non-metastatic breast cancer. Oncotarget 5: 7486-7497, 2014.

168. Sieuwerts AM, Mostert B, Bolt-de Vries J, Peeters D, de Jongh FE, Stouthard JM, Dirix LY, van Dam PA, Van Galen A, de Weerd V, et al: mRNA and microRNA expression profiles in circulating tumor cells and primary tumors of metastatic breast cancer patients. Clin Cancer Res 17: 3600-3618, 2011

169. Shaw JA, Brown J, Coombes RC, Jacob J, Payne R, Lee B, Page K, Hava N and Stebbing J: Circulating tumor cells and plasma DNA analysis in patients with indeterminate early or metastatic breast cancer. Biomarkers Med 5: 87-91, 2011.

170. Peeters DJ, Brouwer A, Van den Eynden GG, Rutten A, Onstenk W, Sieuwerts AM, Van Laere SJ, Huget P, Pauwels P, Peeters M, et al: Circulating tumour cells and lung microvascular tumour cell retention in patients with metastatic breast and cervical cancer. Cancer Lett 356 (2 Pt B): 872-879, 2015.

171. Kurata H, Takakuwa K, Tsuneki I, Aoki Y and Tanaka K: Ovarian tumor cell detection in peripheral blood progenitor cells harvests by RT-PCR. Acta Obstet Gynecol Scand 81: $555-559,2002$

172. Oikonomopoulou K, Scorilas A, Michael IP, Grass L, Soosaipillai A, Rosen B, Murphy J and Diamandis EP: Kallikreins as markers of disseminated tumour cells in ovarian cancer: a pilot study. Tumour Biol 27: 104-114, 2006.

173. Magnowski P, Bochyński H, Nowak-Markwitz E, Zabel M and Spaczyński M: Circulating tumor cells (CTCs)--clinical significance in patients with ovarian cancer. Ginekol Pol 83: 291-294, 2012 (In Polish). 
174. Poveda A, Kaye SB, McCormack R, Wang S, Parekh T, Ricci D, Lebedinsky CA, Tercero JC, Zintl P and Monk BJ: Circulating tumor cells predict progression free survival and overall survival in patients with relapsed/recurrent advanced ovarian cancer. Gynecol Oncol 122: 567-572, 2011.

175. Romero-Laorden N, Olmos D, Fehm T, Garcia-Donas J and Diaz-Padilla I: Circulating and disseminated tumor cells in ovarian cancer: A systematic review. Gynecol Oncol 133: 632-639, 2014.

176. Liu JF, Kindelberger D, Doyle C, Lowe A, Barry WT and Matulonis UA: Predictive value of circulating tumor cells (CTCs) in newly-diagnosed and recurrent ovarian cancer patients. Gynecol Oncol 131: 352-356, 2013.

177. Aktas B, Kasimir-Bauer S, Heubner M, Kimmig R and Wimberger P: Molecular profiling and prognostic relevance of circulating tumor cells in the blood of ovarian cancer patients at primary diagnosis and after platinum-based chemotherapy. Int J Gynecol Cancer 21: 822-830, 2011.

178. Obermayr E, Castillo-Tong DC, Pils D, Speiser P, Braicu I, Van Gorp T, Mahner S, Sehouli J, Vergote I and Zeillinger R: Molecular characterization of circulating tumor cells in patients with ovarian cancer improves their prognostic significance - a study of the OVCAD consortium. Gynecol Oncol 128: 15-21, 2013.

179. Pearl ML, Zhao Q, Yang J, Dong H, Tulley S, Zhang Q, Golightly M, Zucker S and Chen WT: Prognostic analysis of invasive circulating tumor cells (iCTCs) in epithelial ovarian cancer. Gynecol Oncol 134: 581-590, 2014.

180. Zeng L, Liang X, Liu Q and Yang Z: The predictive value of circulating tumor cells in ovarian cancer: A meta analysis. Int J Gynecol Cancer: Apr 17, 2015 (Epub ahead of print).

181. Song J and Nettles JB: Circulating tumor cells in patients with carcinoma in situ of the cervix uteri. Am J Obstet Gynecol 104: 713-726, 1969.
182. Yuan CC, Wang PH, Ng HT, Li YF, Huang TS, Chen CY, Tsai LC and Shyong WY: Detecting cytokeratin 19 mRNA in the peripheral blood cells of cervical cancer patients and its clinical-pathological correlation. Gynecol Oncol 85: 148-153, 2002.

183. Weismann P, Weismanova E, Masak L, Mlada K, Keder D, Ferancikova Z, Vizvaryova M, Konecny M, Zavodna K, Kausitz J, et al: The detection of circulating tumor cells expressing E6/E7 HR-HPV oncogenes in peripheral blood in cervical cancer patients after radical hysterectomy. Neoplasma 56: 230-238, 2009.

184. Alonso-Alconada L, Muinelo-Romay L, Madissoo K, DiazLopez A, Krakstad C, Trovik J, Wik E, Hapangama D, Coenegrachts L, Cano A, et al; ENITEC Consortium: Molecular profiling of circulating tumor cells links plasticity to the metastatic process in endometrial cancer. Mol Cancer 13: 223, 2014.

185. Bogani G, Liu MC, Dowdy SC, Cliby WA, Kerr SE, Kalli KR, Kipp BR, Halling KC, Campion MB and Mariani A: Detection of circulating tumor cells in high-risk endometrial cancer. Anticancer Res 35: 683-687, 2015.

186. Grünewald K, Haun M, Fiegl M, Urbanek M, Müller-Holzner E, Massoner A, Riha K, Propst A, Marth C and Gastl G: Mammaglobin expression in gynecologic malignancies and malignant effusions detected by nested reverse transcriptasepolymerase chain reaction. Lab Invest 82: 1147-1153, 2002.

187. Obermayr E, Sanchez-Cabo F, Tea MK, Singer CF, Krainer M, Fischer MB, Sehouli J, Reinthaller A, Horvat R, Heinze G, et al: Assessment of a six gene panel for the molecular detection of circulating tumor cells in the blood of female cancer patients. BMC Cancer 10: 666, 2010. 